2019

\title{
The Editors' Perspective: Reflecting on Two Years of the Journal of Occupational Therapy Education
}

Renee Causey-Upton

Eastern Kentucky University

Cynthia L. Hayden

Eastern Kentucky University

Dana Howell

Eastern Kentucky University

Follow this and additional works at: https://encompass.eku.edu/jote

Part of the Occupational Therapy Commons

\section{Recommended Citation}

Causey-Upton, R., Hayden, C. L., \& Howell, D. (2019). The Editors' Perspective: Reflecting on Two Years of the Journal of Occupational Therapy Education. Journal of Occupational Therapy Education, 3 (1). https://doi.org/10.26681/jote.2019.030101

This The Editors' Perspective is brought to you for free and open access by Encompass. It has been accepted for inclusion in Journal of Occupational Therapy Education by an authorized editor of Encompass. For more information, please contact Linda.Sizemore@eku.edu. 


\section{The Editors' Perspective: Reflecting on Two Years of the Journal of Occupational Therapy Education}

\section{Keywords}

Research, global, publication

Creative Commons License (c) $(1) \Theta \Theta$

This work is licensed under a Creative Commons Attribution-Noncommercial-No Derivative Works 4.0 License. 


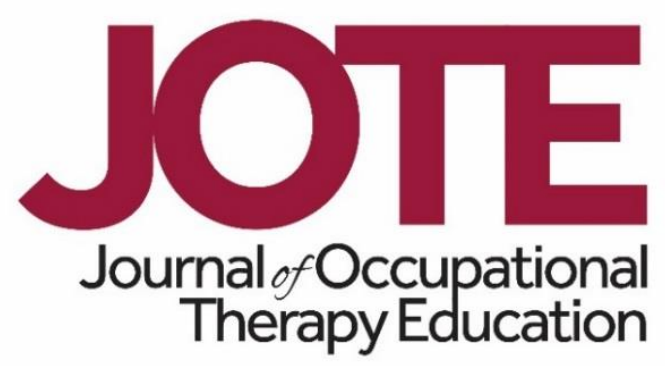

Volume 3, Issue 1

\title{
The Editors' Perspective:
}

Reflecting on Two Years of the Journal of Occupational Therapy Education

\author{
Renee Causey-Upton, PhD, OTD, MS, OTR/L \\ Cindy Hayden, D.H.Ed., OTR/L, CHT \\ Dana M. Howell, PhD, OTD, OTR/L, FAOTA \\ Eastern Kentucky University \\ United States
}

\begin{abstract}
The Journal of Occupational Therapy Education (JOTE) is entering its third year of publication. In April 2017, the first issue was launched in alignment with the profession's Centennial celebration. Two additional issues were published in August and December 2017 to complete Volume 1. During 2018, three issues were published in April, July, and October for Volume 2. In 2019, due to our continued growth, we anticipate expanding to four issues per year.
\end{abstract}

Since the launch of the journal in April 2017, JOTE has received more than 150 manuscript submissions, and published a total of 45 peer-reviewed articles as well as 2 editorials in Volume 1 and 2 of the journal (see Table 1). Original research continues to be the main source of content, followed by educational innovations, and theory.

Table 1

JOTE Publications from Volume 1 and 2

\begin{tabular}{|l|l|l|l|}
\hline \multicolumn{1}{|c|}{ Publication Type } & \multicolumn{2}{c|}{ Frequency Volume 2 } & \multicolumn{1}{c|}{ Total } \\
\hline Original Research & 13 & 18 & 31 \\
\hline Educational Innovation & 5 & 6 & 11 \\
\hline Theory & 2 & 1 & 3 \\
\hline Editorial & 1 & 1 & 2 \\
\hline Total & 21 & 26 & 47 \\
\hline
\end{tabular}


We continued to see a wide range of educational topics in the second volume. Research covered the spectrum of occupational therapy education from the occupational therapy assistant curriculum to continuing education for practicing occupational therapists. Occupational therapy educators researched a variety of teaching methods, such as video instruction, service learning, experiential learning, intraprofessional/interprofessional activities, and online teaching. Practice specific topics that were covered included differences in perceptions and use of evidence-based practice between occupational therapy students and practicing occupational therapists as well as how occupational therapy practice patterns in rural states are influenced by college experiences.

Several articles related to fieldwork experiences, such as: how students apply feedback on fieldwork, role-emerging fieldwork placements, assessment of professional behaviors on clinical rotations, a model for developing professional behaviors on fieldwork, and enhancing self-efficacy for school-based fieldwork educators. Professional behaviors were further addressed in relation to ways to enhance professionalism among students, such as through an on-campus occupational therapy clinic and guided reflection. In addition, both intra and interprofessional education was an area of interest. Collaborative learning experiences included occupational therapy assistant and occupational therapy students as well as psychology, physical therapy, dental hygiene, physician assistant, and pre-professional undergraduate students.

The student experience was prominent in Volume 2, which included a study about how students manage anxiety and stress during their first semester of occupational therapy graduate education. Another article presented a structured coping strategy program for graduate occupational therapy students.

Multiple models and theories were explored in Volume 2 in relation to student outcomes such as leadership skills and professional reasoning, including the Centralized Service Learning Model, Social Change Model of Leadership, Transformative Learning Theory, and Self-Determination Theory. Other articles examined perceptions of entry-level degree requirements and admission requirements for entry-level OTD programs.

JOTE articles have been downloaded more than 7,500 times at the time of publication of this editorial. Articles have been viewed internationally by readers from the United States and 104 other countries such as Ireland, the United Kingdom, France, Australia, Germany, Denmark, the Philippines, Canada, China, Malaysia, and South Africa. Readers from a variety of educational, clinical, government, and other organizations have downloaded JOTE articles during the first two years of publication including the National Health Service, National Institutes of Health, and Department of Education (see our download map here: https://encompass.eku.edu/jote/). There has been a global interest in JOTE publications from readers, and we are excited to see more international submissions as well from countries such as Norway, Cyprus, Australia, Ireland, Canada, and the United Kingdom. 


\section{In This Issue}

We are pleased to present Volume 3, Issue 1 of JOTE with eight high-quality research articles and two educational innovations articles. This issue contains a study related to early concepts of caring in OT students, two studies about self reflection (professional behavior growth and fieldwork), and one examining factors that predict fieldwork performance. There are two reports from the same research study about interdisciplinary service learning projects promoting health. This issue also contains a scoping review on peer supervision competencies and an article on an assessment tool for use with evaluating student clinical competence before fieldwork. The remaining research papers compare outcomes from a master's and entry level OTD program and student perspectives of the OTD experience.

We look forward to continuing to receive high quality submissions to JOTE and hope publications of original research, educational innovation, theory, and technology will positively influence the practice of occupational therapy educators around the nation and the world.

The Editors

Dana M. Howell, PhD, OTD, OTR/L, FAOTA

Cindy Hayden, D.H.Ed., OTR/L, CHT

Renee Causey-Upton, PhD, OTD, MS, OTR/L 